\title{
Representation of the Sciences in Julian Barnes' Fiction
}

\author{
Wei-qiang $\mathrm{MAO}^{1, \mathrm{a},{ }^{*}}$ \\ ${ }^{1}$ School of Foreign Languages, Jiangsu University, \\ 301 Xuefu Road Zhenjiang, 212013, Jiangsu Province, China \\ amozeno@live.com
}

Keywords: Julian Barnes, Science.

\begin{abstract}
Julian Barnes demonstrates a consistent interest in the relationship between science and literature. For him, writing is a substitution of the religious faith destroyed by advances in science. This paper examines how different aspects of science are represented in each of his novels, with an aim to recapitulate Julian Barnes' thought about truth and aging against the background of current studies of the relationship between science and literature.
\end{abstract}

\section{Introduction}

Writing in the era of postmodernism, Barnes demonstrates an unmistakable distrust of scientific truth and endeavors a critique of science. For Barnes, the past is like a piglet "smeared with grease" that refuse capture. [1] There is neither total truth to be discovered in A History of the World in 10 1/2 Chapters nor TAT (The Absolute Truth) to be provided by GPC (general purpose computer) in Staring at the Sun. In stead, there is truth and accuracy in Barnes" fictional widow: "rather than inventing the correct grief for my fictional character, I had merely been predicting my own probable feelings- an easier job." [2]

Julian Barnes sets most of his novels in the shadow or the aftermath of nuclear destruction, Cultural Revolution of 1960s, Thatcherian reinvigoration of Victorian values in the 1980s, globalization and technocracy. Like his contemporary McEwan who believes in the power of literature to tranquilize the agitated aggressor in Saturday, Barnes also believes in the power of literature to batter down the encroachment of science and technology upon humanity. So Barnes uses his writing as a medium to experiment with an epistemology of truth that looks at issues engaged in the posthumanist debates about "the distinction between human and animal, organism and machine", and a philosophy of aging (or the science of gerontology) that will help to ease the cultural anxiety that surrounds moments of technological newness. [3]

The aim of this paper is to recapture and recapitulate Julian Barnes' thought about truth and aging against the background of current studies of the relationship between science and literature.

\section{Trainspotting and Sexuality}

This part centers on Barnes' interest in trainspotting which might have developed during his schooldays commuting between home and City of London School. Like the horse-drawn carriage used by Flaubert both for himself and for his protagonist Emma Bovary as a place for adultery, train carriages carry a similar moral overtone. Voyeurism, sexual hallucinations and talks about whores and syphilis become part of Christopher's experience in train travelling. Observations about trains and the safety of 
travelling on trains in Metroland can find its echo in Railway Law for the Man in the Tran Intended as a Traveling Guide for Public written by the historical figure George Edalji fictionalized in Arthur and George. Barnes must have read the book before the creation of Metroland and Flaubert's Parrot. Doctor Braithwaite, who is as observant as Christopher, demonstrates the same interest in the discussion of syphilis, an illness which might have plagued Flaubert considerably. Braithwaite's failure in his own marriage prompts him to seek comfort from exploring the sexual history of Flaubert, who is thoroughly examined as a patient under his professional eye. As a result, medical science and psychology will be invoked in the discussion of the protagonists' anxiety over sexuality and aging.

\section{Brains within a Brain}

Julian Barnes's second novel Before She Met Me examines how social factors and neurosis affect the function of the different parts of human brain. The evolution from animals to human beings does not guarantee the superiority of man over animal. Neither is the division of man's brain made by Paul D. MacLean (published on Journal of Nervous and Mental Disease, October 1962) into three brains, namely the lowest reptilian part, that of the lower mammals and that of later development of mammals, is not to demonstrate man's difference from animal. Instead, MacLean maintained that three parts must function together and communicate with one another. MacLean pointed out further that the structure of man's brain endowed by nature often casts him into predicaments.

The trouble the protagonist Graham in Before She Met Me is caught in is that the reptilian self always takes the upper hand over his advanced part of mammalian brain. $\mathrm{He}$ is unable to stop himself from imagining the adultery his second wife Ann might have committed before she met him. Playing the detective role that Arthur Conon Doyle practiced, Graham works out the truth hidden in the novels written by his friend Jack about the romance between Jack and Ann, both of whom have tried their best to hide it from Graham. So fancy is turned into fact. Unable to accept the fact that Ann might have kept a relationship with Jack even after she met him, Graham chooses to kill Jack and cut himself to death in front of Ann. Reference to neurology will be made to analyze the war lost by the advanced mammalian brain to the reptilian brain within Graham's brain. I will argue that Graham's first wife Barbara's jealousy and revenge on his adultery plays the butterfly that ultimately leads to Graham's derangement.

\section{A History of the World in 10 1/2 Chapters: A History of Sciences}

Starting from the investigation of the nature of history as a branch of social science, this part aims to examine different discourses of science interacting with each other in the formation of a totalizing truth, which, according to Barnes in the guise of the narrator in the half chapter of this novel, is both unattainable and impossible. Barnes' presentation of science, rather than being mistakenly understood by Daniel Candel in his essay "Julian Barnes' A History of Science in 10 1/2 Chapters" to be an interest limited to the portraying of scientific discoveries or technological products, extends instead to an endeavor to establish an epistemology of truth to question the nature of the philosophy of history and science. [4]

For Barnes, the tale of Noah, the very origin of western civilization, is merely bamboozlement invalidated by evolutionist discovery of various other species not 
included in Noah's selection when the Flood came. The distinction between man and animal in terms of their intelligence is blurred. Natural selection is replaced by Noah's eugenics grounded on his whims, temperaments and his taste for peculiar food. The tale of progress is replaced by a tale of constant bursts and regression with human beings frequently thrown into crisis of existence imposed on them by the ever forward-moving wheel of science. The panic caused by such progress, the fear of death, the dread of aging, according to Julian Barnes, could only be assuaged by his meditation on love conveyed in a language which is scientific in nature.

\section{Evolutionary Economics}

Talking it Over, Love, etc and England, England exhibit Barnes' interest in the evolution of social economies. This part will then expound on how evolutionary theory acts on the life of the characters of these three novels. To justify his behavior in winning over Gillian, his friend Stuart's wife, Oliver sets up a theory of market forces in love and marriage. Disheartened and disillusioned, Stuart goes abroad and adapts himself to the free market of America to practice the knowledge about competition learned from his failure in marriage and becomes very successful in various adventures ranging from banking, joining the catering industry to becoming a green grocer trading organic food, the last of which enables Stuart to expand his business back to Britain. Stuart's acuteness and adeptness at seizing new opportunities in the market of economy boosts up his confidence in the social market of love and marriage opened up by Oliver. He first moves Oliver and Gillian with their daughters out of their poor residence into the house he shared with Gillian before their divorce. Then he offers Oliver a job, which exacerbates Oliver's distress and depression from his failure in his life and career.

If Stuart's success in grocery can be attributed to his concept of "One Stop Shopping", Sir Jack's success can be attributed to the concept of "One Stop Tourism" underlying his theme park England, England, which converges the duplicates of various historical sites and events in the Isle of Wight to the effect that the virtual takes the place of the real and the fanciful takes the place of the factual. The blur of boundary between the factual and the fanciful sets Martha into questioning the morality of such one stop tourism and leads her back to the old England of Albion where the force of scientific and technological development is reduced to the least degree and the Agricultural Show Martha experienced in her childhood is reopened to restore lost traditions, an act incomparable with Sir Jack's atavistic indulgence in babyhood. Reference to Psychiatry in relation to mental break down and schizophrenia will be made to analyze the depression and mania that Oliver and Jack undergo in their fighting for a beachhead in the marketplace.

\section{Forensic Science and Justice}

The boundary between fact and fancy has always been blurred in postmodernist writings to expose the constructed nature of reality and truth. It is especially true with Barnes' Porcupine and Arthur and George, two novels that examine forensic science. The purpose of this part is to discuss how truth is heavily tainted by political purport and the ideological thoughts of the defenders of justice. In Porcupine, the Prosecutor General Peter Solinsky is determined to defeat the former president Stoyo Petkanov both to secure a bright future for himself as a lawyer and to vent his hatred of the President whom he believes has wronged his father and has disgraced him in and out of 
court. He pieces up a tale that Petkanov has murdered his daughter and has signed a decree to authorize the elimination of political opponents. The most telling evidence he could produce at court so far is a piece of paper with a signature of SP, which is in fact made up by Ganin, Head of the Patriotic Security Forces. So the whole procedure is just a "show trial." [5] In Arthur and George, the police went straight to Gorge Adalja's house after a horse was maimed. The evidence produced by the police through autopsy, phrenology and graphology, though loopholes abound, all turned against George. After he was released from prison, George went to Arthur Conan Doyle for help.

Though Arthur's publication of his findings did oblige a committee to make a statement after a review of the whole case that George was "guilty and innocent" and was given "free pardon", George found it "all true, and yet untrue; flattering, yet unflattering; believable yet unbelievable" and that Arthur "was too influenced by his own creation of Holmes." [6] Through a fictional restaging of the miscarriage of law, Barnes expresses his doubt about the role judicial and bureaucratic machinery has played in institutional justice. Therefore, forensic science is invigorated to examine the truth-value of the rhetoric of legal discourse. In the meantime, due attention will also be given to the relationship between reason and spiritualism practiced by Arthur Conan Doyle's from middle age onwards. Though a pseudo-science, spiritualism rose as a result of the "decline in scientific certainty" in later $19^{\text {th }}$ century. [7] On the other hand, Arthur's turn to spiritualism is also enticed by his fear and anxiety about death at middle age, the very symptom of aging. It demonstrates Barnes's interest in exploring the spiritual side of reality, though he claims himself an atheist.

\section{The Height of Sin and Philosophical Suicide}

This part examines Barnes's Staring at the Sun, The Sense of an Ending and Levels of Life to look at different feelings the protagonists of these novels harbor toward death in their advanced age. Life for Jean is as uninteresting as it is for Tony, even less challenging for the widowed narrator of Barnes's latest novel Levels of Life. The biggest challenge Jean has taken in her life is her flight upward to seek the miracle of experiencing sun-set twice within a day, rather than the twice seen sun-rise experienced by Prosser who deliberately seeks death by flying toward the sun. Flight offers Jean an opportunity not to gain the god's view of "seeing for ourselves" discussed in Levels of Life but to gain the certainty of the impossibility of an afterlife: "we had a mortal soul, a destructible soul, and that was perfectly all right." [8]

Jean's certainty in answering her 60-year old son's questions concerning the absolute death, nonsense religion and impermissible suicide forms a sharp contrast with the ineptitude of GPC in denouncing these questions to be unreal. The fact that GPC and TAT are not really supercomputers but young women dutifully feeding answers enables Barnes, Moseley argues, to "introduce some satire on the politics of aging." [9] The critique of science and technology about their ability to provide knowledge in relation to death and immortality becomes harsher in The Sense of an Ending and Levels of Life. In this chapter, gerontology will be introduced to discuss banality of old life, the complacency of old people, the fear of death, and the responsibility toward others. The problem of suicide each of theses three novels has addressed will be discussed in relation to Sartre's reasoning about absurdity. 


\section{Conclusion}

In his novels, Julian Barnes has shown his disbelief in God, whom he thinks has been dead but misses him a lot. Gone with God is not only our belief in religion but also the tale about how to understand our fears of death. So what Barnes misses is the pattern of life represented by the tales of God. In his sadness over the loss of the pattern of life, Barnes turns to art for his consolation, rather than science that precipitated the death of God. For him art is superior to everything and "a book of poetry is preferable to a railway." Therefore, the height and depth of life deprived by the death of God can be retrieved only through writing.

\section{Acknowledgement}

This research was financially supported by Scientific Research Fund of Jiangsu University (15JDG115).

\section{References}

[1] Barnes, Julian. Flaubert' Parrot. London: Jonathan Cape, 1984, p.14.

[2] Barnes, Julian. Levels of Life. London: Jonathan Cape, 2013, p.117.

[3] Haraway, Donna. "A Cyborg Manifesto." Readings in the Philosophy of Technology, Kaplan David (ed.) Oxford: Roman and Littlefield Publishers, Inc. p.163

[4] Bormann, Daniel Candel. "Nature Feminize in Julian Barnes's A History of the World in 10 1/2 Chapters". Atlantis, 1999 (21): 27-41.

[5] Barnes, Julian. The Porcupine. London: Jonathan Cape, 1992, p.113.

[6] Barnes, Julian. Arthur and George. London: Jonathan Cape, 2005, pp.320-328.

[7] Chapple, J.A.V. Science and Literature in the $19^{\text {th }}$ Century. London: Macmillan, 1986, p.56.

[8] Barnes, Julian. Levels of Life. London: Jonathan Cape, 2013, pp.192-193.

[9] Moseley, Merrit. Understanding Julian Barnes [M]. Columbia: University of South Carolina Press, 1997, p.105

[10] Barnes, Julian. Flaubert' Parrot. London: Jonathan Cape, 1984, p.108. 